\title{
Flexible hydrogen fuel cell fabricated on paper with embedded aluminium foil
}

\author{
Yifei Wang ${ }^{l}$, Holly Kwok ${ }^{l}$, Yingguang Zhang ${ }^{l}$, Wending Pan ${ }^{l}$, and Dennis Y.C. Leung ${ }^{l, *}$ \\ ${ }^{1}$ Department of Mechanical Engineering, the University of Hong Kong, Hong Kong, China
}

\begin{abstract}
Direct hydrogen fuel cells are generally heavy and rigid systems based on metal or plastic materials, which are not suitable for various miniwatt and flexible devices. In this study, we have developed a lightweight and flexible fuel cell based on paper substrate embedded with an $\mathrm{Al}$ foil inside, which is used as an in-situ hydrogen source by reaction with an electrolyte solution during operation. Benefited from the inhibited hydroxyl transportation by the porous cellulose network, the vigorous $\mathrm{Al}$ corrosion reaction is well controlled even though strong alkaline electrolyte is adopted, so that the fuel cell can be discharged for more than 5 hours at $1 \mathrm{~mA} \mathrm{~cm}{ }^{-2}(0.83 \mathrm{~V})$ with only $3.5 \mathrm{mg} \mathrm{Al}$ foil. The corresponding faradaic and energy efficiencies are as high as $72 \%$ and $18.3 \%$, respectively. The fuel cell flexibility is also quite good when facing different bending angles. Considering its moderate power output, this flexible paper-based hydrogen fuel cell is especially suitable for powering various miniwatt and flexible devices, such as wearable electronics, biosensors, RFID tags, etc. However, higher power can be obtained by suitable stacking of the fuel cell.
\end{abstract}

\section{Introduction}

Fossil fuels such as coal, oil and natural gas are currently the mainstream energy source worldwide, which is however, not only resource limited but also generating pollution and damage to the environment. Compared with these hydrocarbon fuels, hydrogen fuel is a renewable energy carrier which can be produced through chemical, electrochemical or photocatalytic approaches, which is also pollution-free and carbon-neutral during consumption. Therefore, it is highly feasible and promising for the hydrogen cycle to replace the conventional carbon cycle as long as the associated technology develops, which will lead to a "hydrogen economy" in the future [1].

To utilize hydrogen, fuel cell is one of the most efficient devices which can convert the chemical energy in the hydrogen directly to electricity. Based on their electrolytes, fuel cell can be classified into many sub-types, including proton exchange membrane fuel cell (PEMFC), solid oxide fuel cell, alkaline fuel cell, phosphoric acid fuel cell, molten carbonate fuel cell, microfluidic (membraneless) fuel cell (MFC), etc. [2] Among them, the PEMFC receives great $R \& D$ attention especially in the transportation and portable application sectors. This is mainly because of its low temperature operation, high power

* Corresponding author: ycleung@hku.hk 
output together with mature membrane electrolyte technology [3]. Nevertheless, to date, most of the PEMFCs are inflexible reactors based on metal or plastic framework and multilayer cell configuration, which are not only heavyweight and complex, but also require sophisticated and expensive fabrication. These shortcomings may be tolerable for large systems such as electric vehicle, but are much less favorable for portable electronics, especially the flexible electronics. Therefore, great efforts have been made in the past decade to develop flexible fuel cells in order to expand the application prospect of this technology [4-13]. Tominaka et al. [10] fabricated a bendable fuel cell on cycloolefin polymer substrate by hot embossing. With methanol as fuel, this cell could generate a peak power density of $83 \mu \mathrm{W} \mathrm{cm}$ c $^{-2}$. Weinmueller et al. [11] also designed a flexible methanol fuel cell on a thin polymer film of photosensitive SU-8. This time a much higher power density of $19 \mathrm{~mW} \mathrm{~cm}^{-2}$ was achievable, and the cell functioned normally under both single radius bending condition and S-shape bending condition. Hsu et al. [7] embedded metal wires into carbon fibre bunches as a novel flexible current collector. The subsequent flexible PEMFC achieved similar performance to the conventional nonflexible cell with hydrogen fuel, which was also almost unaffected when facing different bending curvatures. Chang et al. [4-6] have done a series of work to develop flexible polydimethylsiloxanebased hydrogen PEMFC. Using Ag nano-wire percolation networks as current collector, their device could achieve even better power output at bending status than that of flat status, which was benefited from the decreased resistance originated from the increased compressive force normal to the membrane electrode assembly. In general, since the polymer electrolyte membrane is intrinsically flexible, the key issue for developing flexible PEMFC is to design flexible gas diffusion layer, current collector and bipolar plates.

Despite its research progress, the current PEMFC is generally high cost because of the expensive polymer electrolyte membrane (e.g. Nafion membrane). In addition, the membrane requires delicate water balance in order to maintain a normal and stable fuel cell operation, leading to sophisticated water management subsystem [14, 15]. Furthermore, even though the fuel cell itself is flexible, a bulky hydrogen storage unit and associated delivery tubing are still requisite, which will impair the flexibility of the whole system. Recently, a novel type of paper-based fuel cell (PBFC) is proposed, which employs the capillary action of cellulose paper to passively transport the aqueous electrolyte [16-20]. In this manner, the PBFC is not only cost-efficient and structurally-simple, but also highly flexible. Various fuels have been studied in the PBFC, including methanol [17], formate [16], glucose [18], hydrogen peroxide [19], etc. As for hydrogen, since paper is not a gastight material, a plastic shell is required to encapsulate the PBFC inside, which inevitably sacrifice the device flexibility [20]. In this work, we aim to develop a flexible hydrogen PBFC. To eliminate the necessity for hydrogen storage and to prevent the hydrogen from escaping, an Al foil was innovatively utilized and embedded inside the paper substrate as hydrogen source. The other fuel cell components were directly deposited onto the paper surface. In this manner, a low-cost, concise, lightweight and flexible fuel cell system was developed. To the best of our knowledge, this novel cell design has never been investigated before.

\section{Experimental}

\subsection{Fuel cell design and fabrication}

Unlike conventional rigid fuel cells based on either metal or plastic framework, the present flexible fuel cell was built entirely within a single piece of paper substrate. Fig. 1 (a) shows the schematic diagram of its working principle. A thin layer of Al was stored inside the 
paper as hydrogen source, while the hydrogen oxidation reaction (HOR) anode and oxygen reduction reaction (ORR) cathode were directly deposited onto the opposite side of the paper surface. During operation, an alkaline electrolyte solution was provided and wicked into the paper substrate by capillary action. The Al layer would react with the electrolyte to generate $\mathrm{H}_{2}$ for the anode side, while $\mathrm{O}_{2}$ from the ambient air was utilized by the cathode side. Consequently, electricity can be generated continuously until the Al layer is exhausted. Fig. 1(b) illustrates the exploded view of the present flexible fuel cell. First of all, an $\mathrm{Al}$ foil (kitchen foil, 98.3\% purity, $1 \mathrm{~cm} \mathrm{x} 1 \mathrm{~cm}$ ) was embedded inside a piece of home-made paper during the paper-making process. Next, two $5 \times 5 \mathrm{Ag}$ grids $\left(1 \mathrm{~cm}^{2}\right.$ total area) were drawn on opposite sides of the paper, which covered exactly the Al foil inside. They were also connected to $\mathrm{Cu}$ tape ends for external connection. Afterwards, the anode and cathode catalyst inks were deposited onto corresponding grids by a pipette, respectively. For the anode side, the catalyst ink was composed of $50 \mathrm{mg} \mathrm{Pt} / \mathrm{C}$ (Johnson Matthey, $60 \mathrm{wt} . \% \mathrm{Pt}), 2.5 \mathrm{mg}$ Nafion binder and $1 \mathrm{~mL}$ ethanol-water (1:1) solvent, which were sonicated for $30 \mathrm{~min}$ to achieve uniform distribution. For the cathode side, the catalyst ink was composed of $50 \mathrm{mg} \mathrm{MnO}_{2} / \mathrm{CNT}$ (home-made by co-precipitation method [21], 60 wt. $\left.\% \mathrm{MnO}_{2}\right), 2.5 \mathrm{mg}$ Nafion binder and $1 \mathrm{~mL}$ ethanol-water $(1: 1)$ solvent, which were also sonicated for $30 \mathrm{~min}$. For each cell, $40 \mu \mathrm{L}$ of the anode ink and $20 \mu \mathrm{L}$ of the cathode ink were deposited, respectively, leading to an anode catalyst loading of $1.2 \mathrm{mg} \mathrm{cm}^{-2} \mathrm{Pt}$ and cathode catalyst loading of $0.6 \mathrm{mg} \mathrm{cm} \mathrm{MnO}_{2}$. Here it is worth mentioning that $\mathrm{Pt}$ was temporarily utilized in this work in order to testify our flexible fuel cell concept first, which will be replaced by non-noble HOR catalysts such as Ni in our future work. After electrode deposition, a sealing tape was attached to the anode surface in order to isolate it from ambient air. Otherwise, a significant mix potential would be generated on the anode side, leading to fuel cell failure. The final prototype was $100 \mathrm{mg}$ in weight and was highly flexible.

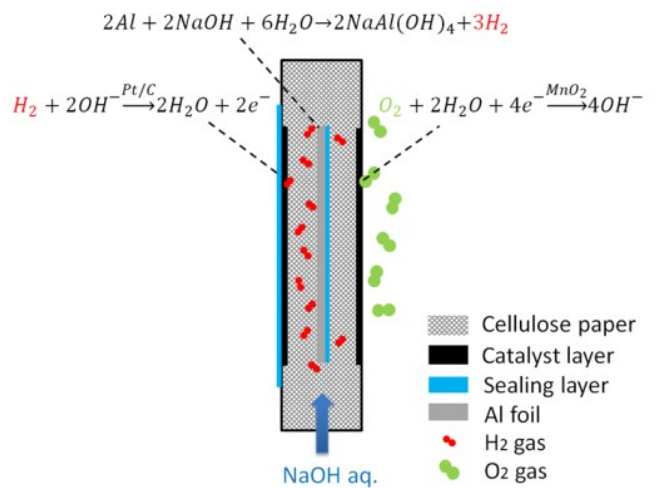

(a)

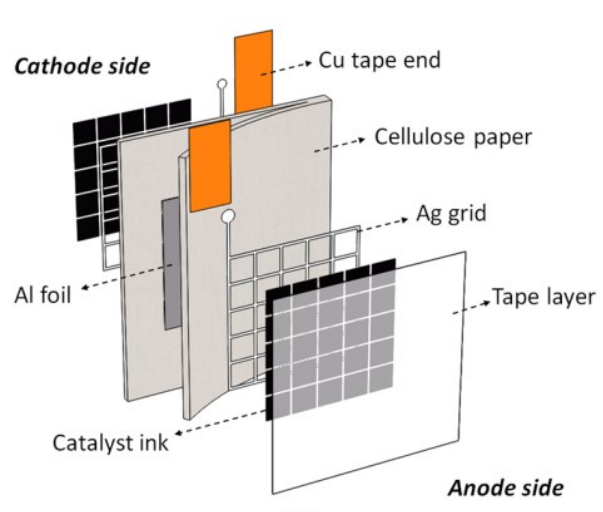

(b)

Fig. 1 Schematic diagrams of the flexible hydrogen PBFC: (a) Working principle; (b) Exploded view of the cell structure.

\subsection{Fuel cell testing}

The present fuel cell was tested with $3 \mathrm{M} \mathrm{NaOH}$ electrolyte. This concentration was used because a higher concentration would shrink the paper substrate and deform the deposited $\mathrm{Ag}$ grids and electrodes on it. The fuel cell was suspended vertically, with its $\mathrm{Cu}$ ends connected to an electrochemical work station (CHI 760E). Its paper end was contacted with $0.5 \mathrm{~mL}$ electrolyte solution to facilitate the capillary absorption process. Once the electrode 
area was totally wetted, the fuel cell OCV was recorded until it reached a stable value. Afterwards, the fuel cell polarization curve was obtained by Linear Sweep Voltammetry (LSV) from OCV to $0 \mathrm{~V}$, at a sweep rate of $5 \mathrm{mV} \mathrm{s}^{-1}$. During the sweep, the cathodic potential was also recorded simultaneously by a multimeter, which was connected to both the fuel cell cathode and a reference electrode $(\mathrm{Ag} / \mathrm{AgCl}$ in saturated $\mathrm{KCl})$. The tip of the reference electrode was inserted into the electrolyte drop.

To investigate the fuel cell discharge stability and efficiency, galvanostatic dischage test was conducted at different current densities. With a specific amount of embedded Al (3.5 $\mathrm{mg}$ for a $1 \mathrm{~cm}^{2}$ foil), both the faradaic efficiency and energy efficiency were calculated by the following equations, respectively.

$$
\begin{gathered}
\varepsilon_{\text {faradaic }}=\frac{i A t}{m C \delta} \\
\varepsilon_{\text {energy }}=\frac{V}{U} \cdot \varepsilon_{\text {faradaic }}
\end{gathered}
$$

where $\varepsilon$ is the efficiency, $\mathrm{i}$ is the discharge current density $\left.(\mathrm{mA} \mathrm{cm})^{-2}\right), \mathrm{A}$ is the electrode area $\left(\mathrm{cm}^{2}\right), \mathrm{t}$ is the discharge time $(\mathrm{h}), \mathrm{m}$ is the mass of $\mathrm{Al}$ foil $(0.0035 \mathrm{~g}), \mathrm{C}$ is the $\mathrm{Al}$ specific capacity $\left(2980 \mathrm{~mA} \mathrm{~h} \mathrm{~g}{ }^{-1}\right), \delta$ is the $\mathrm{Al}$ purity, $\mathrm{V}$ is the discharge voltage, and $\mathrm{U}$ is the theoretical voltage $(2.7 \mathrm{~V}$ for $\mathrm{Al})$.

\section{Results \& Discussion}

\subsection{Fuel cell performance}

The OCV characteristic of the fuel cell was first studied after providing the alkaline electrolyte. As shown in Fig. 2(a), it took about 8 minutes before the OCV climbed to a steady value of $0.93 \mathrm{~V}$. At the first 4 minutes, the OCV was even negative. Afterwards, the OCV encountered a gradual and stable rise up. This is due to the corrosion of Al that resulted in slow accumulation of $\mathrm{H}_{2}$ gas inside the paper substrate. At the first 4 minutes, the concentration of $\mathrm{H}_{2}$ was negligible, so that the remaining air inside the paper would cause an ORR potential on the anode side (same as the cathode side). Since Pt is more active for ORR than $\mathrm{MnO}_{2}$, the anode ORR potential would be more positive than that of the cathode, leading to a negative OCV. During the next 4 minutes, the $\mathrm{H}_{2}$ concentration kept increasing, so that the HOR potential started to dominate the anode side, leading to a gradually elevating OCV. The final value of $0.93 \mathrm{~V}$ was normal compared with those in the literature [22].

After stabilization of the OCV, the polarization curves of three cells were recorded and compared in Fig. 2(b). At the higher voltage region (above $0.6 \mathrm{~V}$ ), the polarization curves were very straight and quite similar with each other, which were dominated by ohmic resistance. However, at the lower voltage region (below $0.6 \mathrm{~V}$ ), the curves encountered a sharp drop and the differences between them was quite evident, probably due to the severe mass transport resistance. As shown in Fig. 2(c), this mass transport resistance was mainly from the anode side, indicating a starvation of $\mathrm{H}_{2}$ at the lower voltage region. This $\mathrm{H}_{2}$ starvation was quite random for each cell tested, so that the curve repeatability at lower voltage was not as good as that at higher voltage. In the following sections, an averaged

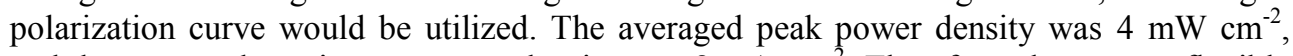
and the averaged maximum current density was $8 \mathrm{~mA} \mathrm{~cm}{ }^{-2}$. Therefore, the present flexible hydrogen PBFC is more suitable for miniwatt applications with low current drain. 
Fig. 2(d) shows the battery discharge curves at current densities of 1,2 and $5 \mathrm{~mA} \mathrm{~cm}^{-2}$, with only $3.5 \mathrm{mg}$ embedded $\mathrm{Al}$ foil as $\mathrm{H}_{2}$ source. At 1 and $2 \mathrm{~mA} \mathrm{~cm}^{-2}$, the discharge curves were very stable until a sudden stop due to the exhaustion of the Al. This result indicates that the generation of hydrogen in the present flexible fuel cell was a very stable process, which supplied hydrogen to the anode at a constant rate. However, when the discharge current density was elevated to $5 \mathrm{~mA} \mathrm{~cm}^{-2}$, the curve started to oscillate, which is probably due to the insufficient supply rate of $\mathrm{H}_{2}$. Nevertheless, the discharge process could still be sustained until the Al foil exhausted. Higher discharge current densities than $5 \mathrm{~mA} \mathrm{~cm} \mathrm{~cm}^{-2}$ would lead to a quick drain up of the fuel cell (not shown in the figure). The battery lifetime and discharge efficiencies were all summarized in Table 1. It is interesting to note that even with only $3.5 \mathrm{mg} \mathrm{Al}$, the fuel cell could work for 333.3 minutes stably at $1 \mathrm{~mA} \mathrm{~cm} \mathrm{c}^{-2}$, leading to a high faradaic efficiency of $54.3 \%$ and energy efficiency of $16.7 \%$. The highest faradaic efficiency of $72.0 \%$ was obtained at $5 \mathrm{~mA} \mathrm{~cm}$, while the highest energy efficiency of $18.3 \%$ appeared at $2 \mathrm{~mA} \mathrm{~cm}^{-2}$. All these results prove that the generation of hydrogen in the present flexible fuel cell is a slow and stable process, while the wetted cellulose paper may also help to seal and store the generated $\mathrm{H}_{2}$, preventing them from quick leakage into the ambient air.

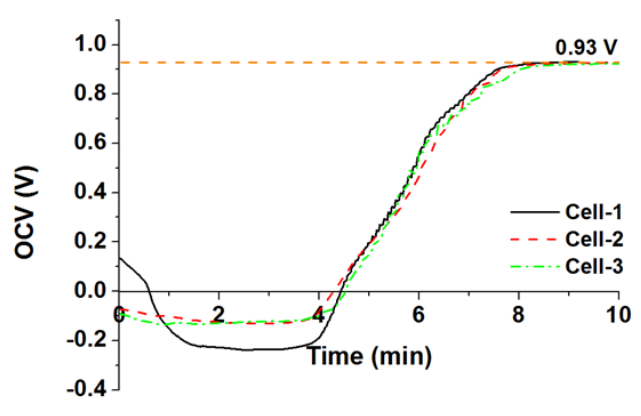

(a)

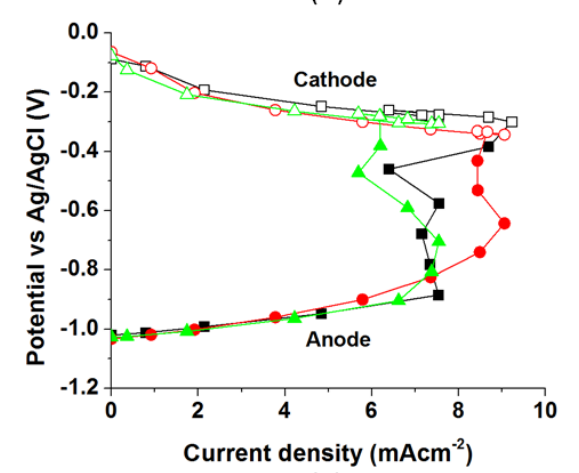

(c)

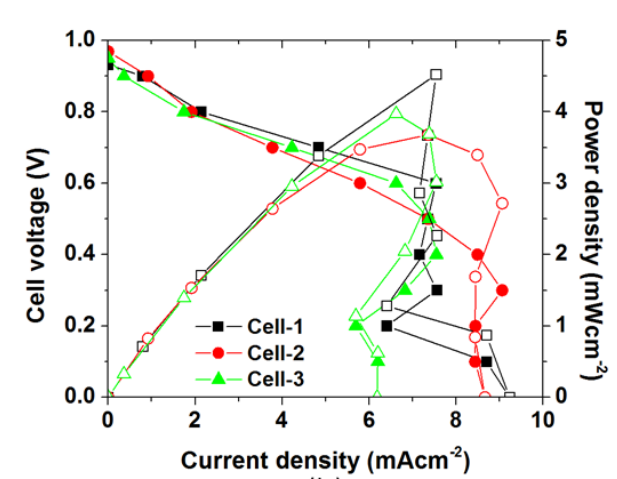

(b)

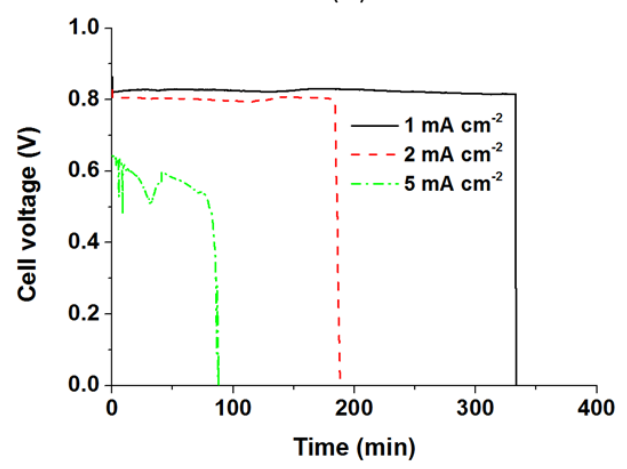

(d)

Fig. 2. Electrochemical testing of the present flexible hydrogen fuel cell: (a) Initiation of the cell OCV; (b) Polarization curve tested with $3 \mathrm{M} \mathrm{NaOH}$ at room temperature; (c) Single electrode polarization; (d) Galvanostatic discharge with $3.5 \mathrm{mg} \mathrm{Al}$ at different current densities. 
Table 1. Summary of the fuel cell lifetime and discharge efficiencies

\begin{tabular}{|c|c|c|c|}
\hline $\begin{array}{c}\text { Current } \\
\text { density }\end{array}$ & $\begin{array}{c}\text { Battery } \\
\text { lifetime }\end{array}$ & $\begin{array}{c}\text { Faradaic } \\
\text { efficiency }\end{array}$ & $\begin{array}{c}\text { Energy } \\
\text { efficiency }\end{array}$ \\
\hline $1 \mathrm{~mA} \mathrm{~cm}^{-2}$ & $333.3 \mathrm{~min}$ & $54.3 \%$ & $16.7 \%$ \\
\hline $2 \mathrm{~mA} \mathrm{~cm}$ & $188.3 \mathrm{~min}$ & $61.2 \%$ & $18.3 \%$ \\
\hline $5 \mathrm{~mA} \mathrm{~cm}{ }^{-2}$ & $88.5 \mathrm{~min}$ & $72.0 \%$ & $14.6 \%$ \\
\hline
\end{tabular}

\subsection{Comparison of $\mathrm{H}_{2}$ generation rate}

The slow and extended $\mathrm{Al}$ corrosion process in this work conflicts with the common sense that $\mathrm{Al}$ generally reacts vigorously with strong alkaline solution. To figure out the reason behind, a comparative study between a bare Al foil and a paper-embedded Al foil in alkaline was conducted by a drainage method as shown in Fig. 3(a). The volume of collected $\mathrm{H}_{2}$ gas was recorded with a time step of $1 \mathrm{~min}$ for bare $\mathrm{Al}$ and $10 \mathrm{~min}$ for embedded Al, immediately after the Al was immersed into the alkaline. Fig. 3(b) shows the testing result with averaged values and error bars, which indicates that the corrosion rate was much slower of the embedded $\mathrm{Al}$ foil than that of the bare $\mathrm{Al}$ foil. For the former, the process could last for nearly an hour, while it was only 6 minutes for the latter case. In addition, both the two cases obtained a total gas volume of $4.8 \mathrm{~mL}$ which is the theoretical value of $3.5 \mathrm{mg} \mathrm{Al}$ foil at room temperature, proving the reliability of this drainage testing method. The average $\mathrm{H}_{2}$ generation rate was $80 \mu \mathrm{L} \mathrm{min}^{-1}$ for the embedded $\mathrm{Al}$ and $800 \mu \mathrm{L}$ $\mathrm{min}^{-1}$ for the bare Al. This difference is mainly because of the cellulose paper that wrapped the $\mathrm{Al}$ foil, whose micro fibre network helps to restrict the contact between the Al surface and alkaline solution. According to Bruggeman's diffusion model [23], the micro-scale pores of the paper will greatly decrease the effective diffusion coefficient of hydroxyl ions inside the paper, which consequently suppresses the $\mathrm{Al}$ corrosion and $\mathrm{H}_{2}$ generation. However, it is worth noticing that the $\mathrm{H}_{2}$ generation process in Fig. 2(d) could last as long as 5.6 hours, while it was only 1 hour in Fig. 3(b). This is mainly because that, in the former case only the end of paper was in contact with the alkaline, while in the latter case all the paper was immersed inside. Therefore, the diffusion path of the former is much longer $(2.5 \mathrm{~cm}$, length of the paper) than that of the latter $(0.1 \mathrm{~cm}$, half thickness of the paper), leading to an even longer corrosion time.

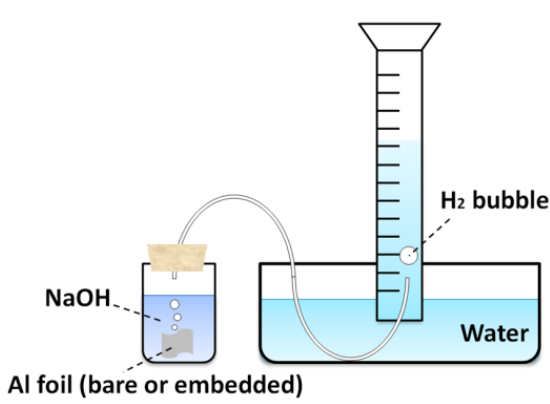

(a)

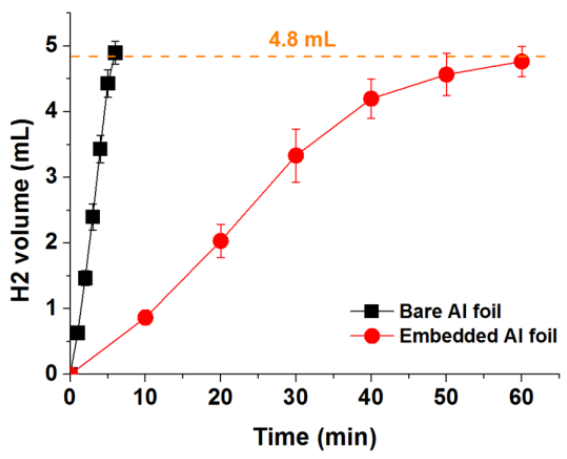

(b)

Fig. 3 Comparative study of the $\mathrm{H}_{2}$ generation rate between a bare $\mathrm{Al}$ foil and an embedded $\mathrm{Al}$ foil in paper: (a) Schematic diagram of the drainage method; (b) $\mathrm{H}_{2}$ generation rate with $3.5 \mathrm{mg} \mathrm{Al}$ foil and 5 $\mathrm{mL} 3 \mathrm{M} \mathrm{NaOH}$ solution. 


\subsection{Study of fuel cell flexibility}

Since cellulose paper was utilized as cell substrate and all other cell components such as ink-based electrode, Ag grid current collector and Al foil were flexible, the present hydrogen fuel cell was intrinsically a flexible power source, which can be applied in many flexible devices such as wearable electronics, biosensors, RFID tags, etc. To investigate its flexibility, the effect of bending angle on cell power output was studied. As shown in Fig. 4(a), the fuel cell was bended by the middle of its electrode from $45^{\circ}$ to $135^{\circ}$, with the airbreathing cathode inside and the anode outside, while their polarization curves were compared in Fig. 4(b) and 4(c). In general, the bending has slightly decreased the fuel cell peak power density from 4 to $3.0-3.5 \mathrm{~mW} \mathrm{~cm}^{-2}(12.5-25 \%$ loss), while the OCV was not affected. However, it is interesting to find that the $\mathrm{H}_{2}$ mass transport loss was greatly alleviated by the bending process, extending the maximum current density from 8 to 10.7 $11.7 \mathrm{~mA} \mathrm{~cm}^{-2}$ (33.8-46.3\% increase). This is probably because that the bending process has improved the contact between the $\mathrm{Al}$ foil and the paper substrate, leading to higher $\mathrm{Al}$ corrosion and $\mathrm{H}_{2}$ generation rates. However, the bending did impair the electric conductivity of the electrodes, resulting in slightly lower power output at the high voltage region. In summary, the fuel cell exhibits good flexibility and will be competent for powering various flexible miniwatt devices.

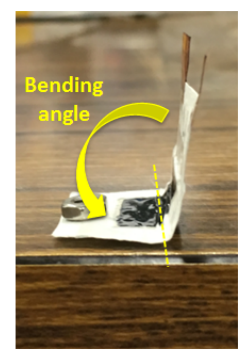

(a)

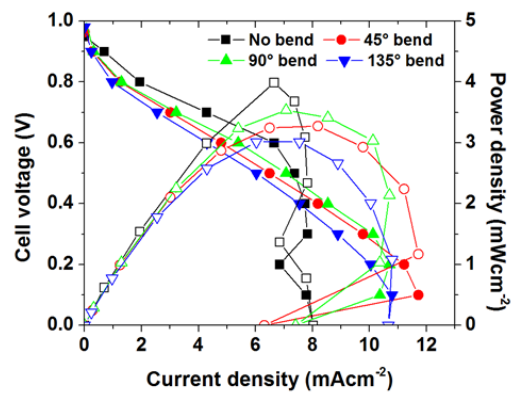

(b)

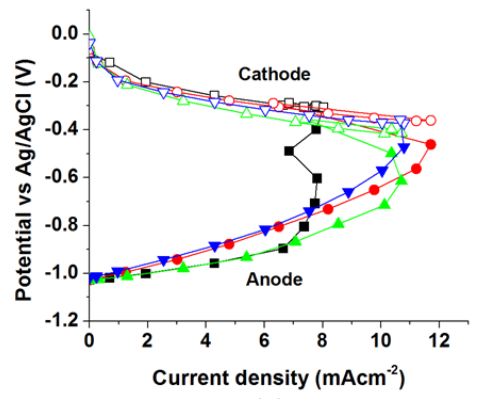

(c)

Fig. 4 Investigation of the fuel cell flexibility: (a) The bended fuel cell prototype; (b) Polarization curve tested at different bending angles; (c) Single electrode polarization.

\section{Conclusion}

In this work, a lightweight and compact flexible fuel cell system is developed by using cellulose paper as substrate. An embedded Al foil inside the paper is innovatively utilized as the hydrogen fuel source, which produces hydrogen in-situ via the $\mathrm{Al}-\mathrm{H}_{2} \mathrm{O}$ reaction. In addition, ink-based flexible electrodes are also deposited directly onto the paper surface. With alkaline as electrolyte, the fuel cell can provide an OCV of $0.93 \mathrm{~V}$, a peak power density of $4 \mathrm{~mW} \mathrm{~cm}^{-2}$ and a maximum current density of $8 \mathrm{~mA} \mathrm{~cm}{ }^{-2}$. Benefitted from protective effect of the paper substrate, the $\mathrm{Al}$ corrosion is found to be a gentle and mild process, which can continuously provide $\mathrm{H}_{2}$ for more than 5 hours even with only $3.5 \mathrm{mg}$ Al. Consequently, the cell discharge faradaic and energy efficiency are as high as $72 \%$ and $18.3 \%$, respectively. Finally, the fine fuel cell flexibility is also well demonstrated by bending it into different angles.

The authors would like to acknowledge the CRCG grant of the University of Hong Kong and the SZSTI of Shenzhen Municipal Government to provide funding support to this project. 


\section{References}

1. G.W. Crabtree, M.S. Dresselhaus, M.V. Buchanan, Phys Today, 57, 39-44 (2004).

2. R. O'hayre, S.-W. Cha, F.B. Prinz, W. Colella, Fuel cell fundamentals (John Wiley \& Sons 2016).

3. V. Mehta, J.S. Cooper, J. Power Sources, 114, 32-53 (2003).

4. I. Chang, T. Park, J. Lee, H.B. Lee, S. Ji, M.H. Lee, S.H. Ko, S.W. Cha, Int. J. Hydrogen Energy, 39, 7422-7427 (2014).

5. I. Chang, T. Park, J. Lee, H.B. Lee, S.H. Ko, S.W. Cha, Int. J. Hydrogen Energy, 41, 6013-6019 (2016).

6. I. Chang, T. Park, J. Lee, M.H. Lee, S.H. Ko, S.W. Cha, J. Mater. Chem. A, 1, 85418546 (2013).

7. F.-K. Hsu, M.-S. Lee, C.-C. Lin, Y.-K. Lin, W.-T. Hsu, J. Power Sources, 219, 180187 (2012).

8. T. Ito, K. Kimura, M. Kunimatsu, Electrochem. Commun., 8, 973-976 (2006).

9. T. Park, I. Chang, H.B. Lee, S.H. Ko, S.W. Cha, Int. J. Hydrogen Energy, 42, 18841890 (2017).

10. S. Tominaka, H. Nishizeko, J. Mizuno, T. Osaka, Energy Environ. Sci, 2, 10741077 (2009).

11. C. Weinmueller, G. Tautschnig, N. Hotz, D. Poulikakos, J. Power Sources, 195, 3849-3857 (2010).

12. J. Wheldon, W.-J. Lee, D.-H. Lim, A.B. Broste, M. Bollinger, W.H. Smyrl, Electrochem. Solid-State Lett., 12, B86-B89 (2009).

13. A. wins Army, Fuel Cells Bulletin (2010).

14. E. Kjeang, N. Djilali, D. Sinton, J. Power Sources, 186, 353-369 (2009).

15. S.A.M. Shaegh, N.-T. Nguyen, S.H. Chan, Int. J. Hydrogen Energy, 36, 5675-5694 (2011).

16. T.S. Copenhaver, K.H. Purohit, K. Domalaon, L. Pham, B.J. Burgess, N.

Manorothkul, V. Galvan, S. Sotez, F.A. Gomez, J.L. Haan, Electrophoresis, 36, 1825-1829 (2015).

17. J. Esquivel, F. Del Campo, J.G. de la Fuente, S. Rojas, N. Sabate, Energy Environ.

Sci, 7, 1744-1749 (2014).

18. A. Dector, J. Galindo-de-la-Rosa, D. Amaya-Cruz, A. Ortíz-Verdín, M. GuerraBalcázar, J. Olivares-Ramírez, L. Arriaga, J. Ledesma-García, Int. J. Hydrogen Energy, 42, 27979-27986 (2017).

19. S.M.M. Ehteshami, M. Asadnia, S.N. Tan, S.H. Chan, J. Power Sources, 301, 392395 (2016).

20. J.P. Esquivel, J. Buser, C. Lim, C. Dominguez, S. Rojas, P. Yager, N. Sabate, J. Power Sources, 342, 442-451 (2017).

21. C. Xu, B. Li, H. Du, F. Kang, Y. Zeng, J. Power Sources, 180, 664-670 (2008).

22. S.M. Mitrovski, R.G. Nuzzo, Lab on a Chip, 6, 353-361 (2006).

23. V.D. Bruggeman, Annalen der physik, 416, 636-664 (1935). 